medRxiv preprint doi: https://doi.org/10.1101/2021.03.03.21252813; this version posted March 5, 2021. The copyright holder for this preprint (which was not certified by peer review) is the author/funder, who has granted medRxiv a license to display the preprint in perpetuity.

It is made available under a CC-BY-NC-ND 4.0 International license .

\title{
Maternal Levels of Acute Phase Proteins in Early Pregnancy and Risk of Autism Spectrum Disorders in Offspring
}

Martin Brynge, $\mathrm{MD}^{1}$; Renee M Gardner, $\mathrm{PhD}^{1}$; Hugo Sjöqvist, $\mathrm{MS}^{1}$; Håkan Karlsson*, $\mathrm{PhD}^{2}$; and

Christina Dalman*, MD, $\mathrm{PhD}^{1,3}$

1. Department of Global Public Health, Karolinska Institutet, Stockholm, Sweden, 17177

2. Department of Neuroscience, Karolinska Institutet, Stockholm, Sweden, 17177

3. Centre for Epidemiology and Community Medicine, Stockholm County Council, Stockholm, Sweden, 17129

*Indicates that the authors made an equal contribution to the work.

\section{Corresponding author:}

Martin Brynge

Department of Global Public Health (K9)

Karolinska Institutet

SE-171 77 Stockholm, Sweden

m.brynge@ki.se

+46702791128

NOTE: This preprint reports new research that has not been certified by peer review and should not be used to guide clinical practice. 
medRxiv preprint doi: https://doi.org/10.1101/2021.03.03.21252813; this version posted March 5, 2021. The copyright holder for this preprint (which was not certified by peer review) is the author/funder, who has granted medRxiv a license to display the preprint in perpetuity. It is made available under a CC-BY-NC-ND 4.0 International license .

\begin{abstract}
Previous research supports a contribution of early-life immune disturbances in the etiology of autism spectrum disorders (ASD). Biomarker studies of the maternal innate (non-adaptive) immune status related to ASD risk have focused on one of the acute phase proteins (APP), C-reactive protein (CRP), with conflicting results. We evaluated levels of eight different APP in maternal serum samples drawn in first trimester, from 318 mothers to ASD-cases and 429 mothers to ASD-unaffected controls, nested within the register-based Stockholm Youth Cohort. Overall, we found no general trend of high levels of maternal APP being associated with increased risk of ASD. In contrast, maternal levels of CRP in the lowest compared to the middle tertile were associated with increased risk of ASD without ID or ADHD in offspring $(\mathrm{OR}=2.15,95 \% \mathrm{Cl} 1.17-3.93)$. Further, levels of maternal ferritin in the lowest $(\mathrm{OR}=$ 1.82, $95 \% \mathrm{Cl} 1.19-2.78)$ and highest $(\mathrm{OR}=1.74,95 \% \mathrm{Cl} 1.16-2.60)$ tertiles were associated with increased risk of any ASD diagnosis in offspring, with stronger associations still between the lowest $(\mathrm{OR}=3.58,95 \% \mathrm{Cl} 1.79-7.17)$ and highest $(\mathrm{OR}=3.20,95 \% \mathrm{Cl} 1.62-6.29)$ tertiles of ferritin and risk of ASD with ID. The biological interpretation of lower CRP-levels among mothers to ASD-cases is not clear but might be related to the function of the maternal innate immune system. The finding of aberrant levels of ferritin conferring risk of ASD-phenotypes indicates a plausibly important role of iron during neurodevelopment.
\end{abstract}


medRxiv preprint doi: https://doi.org/10.1101/2021.03.03.21252813; this version posted March 5, 2021. The copyright holder for this preprint (which was not certified by peer review) is the author/funder, who has granted medRxiv a license to display the preprint in perpetuity.

It is made available under a CC-BY-NC-ND 4.0 International license.

\section{Introduction}

The etiology of autism spectrum disorders (ASD) is complex, with plausible contributions of both genetic variation and early environmental exposures. ${ }^{1}$ ASD often co-occurs with other developmental disorders such as intellectual disability (ID) and attention deficit/hyperactivity disorder (ADHD) ${ }^{2,3}$ defining diagnostic sub-groups with potentially different etiological pathways in terms of genetic and environmental influences. ${ }^{4}$

Evidence that immune-related proteins play pleiotropic roles during neurodevelopment and observations of immune anomalies among ASD-affected individuals ${ }^{5,6}$ have led to the hypothesis that immune dysregulation during early life increases risk of ASD.6-8 Experimental animal models of maternal immune activation report autism-like phenotypes in the offspring, with decreased socialization and restricted patterns of behavior. ${ }^{9}$ However, the validity of such animal models for ASD remains to be established. ${ }^{10}$ Nevertheless, observational studies suggest that events associated with inflammation, such as maternal autoimmune disease, obesity and infections during pregnancy, are linked to ASD. ${ }^{11-15}$ The role of inflammation per se in the mechanisms underlying these associations is uncertain, and the observed associations may also partly be explained by genetic confounding. ${ }^{16-18}$

To understand if the maternal immune activation hypothesis is relevant for ASD, numerous studies have explored maternal immune-related biomarkers from blood samples collected during pregnancy.

These studies have mostly focused on cytokines, with inconsistent results. ${ }^{19-21}$ Cytokines are powerful regulators of the immune system that also play roles in CNS development, but quantitation is technically challenging due to generally low baseline levels with transient secretion patterns and short half-lives. The acute phase proteins (APP) are involved in the initial non-adaptive (innate) immune response, ${ }^{22}$ although several APP exhibit additional functions, not apparently related to immune function. ${ }^{23-25}$ They generally have longer half-lives compared to cytokines and base-line concentrations in the measurable range. The few previous studies on gestational APP and risk of ASD, measured only one of the APP, C-reactive protein (CRP), ${ }^{26-29}$ with inconsistent results.

In the current study, we measured eight different APP in sera collected in the first trimester of pregnancy and estimated the risk of ASD in the offspring associated with the individual APP, using a large, well-characterized population-based cohort.

\section{Materials and Methods}


medRxiv preprint doi: https://doi.org/10.1101/2021.03.03.21252813; this version posted March 5, 2021. The copyright holder for this preprint (which was not certified by peer review) is the author/funder, who has granted medRxiv a license to display the preprint in perpetuity.

It is made available under a CC-BY-NC-ND 4.0 International license.

\section{Study Population}

The present study employed a case-cohort study design nested within the population-based register linkage Stockholm Youth Cohort (SYC). ${ }^{30}$ The source population consisted of children born 1996-2000 ( $n=98$ 597) (Supplementary Figure 1). In Stockholm County, maternal serum samples obtained during the national screening program of pregnant women have been stored frozen since 1998 . We retrieved $0.2 \mathrm{ml}$ serum from all available maternal sera samples, for ASD-cases $(n=430)$ and mothers to control individuals ( $n=549$ ), from those individuals who also had a neonatal dried blood spots (NDBS) as described in detail previously. ${ }^{31}$ Samples were obtained at median gestational week 10.6 (interquartile range: $9.3-12.5$ weeks) representing a period near the end of the first trimester.

For the analysis in this study, we included only those samples drawn in the first trimester ( $\leq 13$ weeks), since maternal serum proteins may vary by gestational age due to maternal blood volume expansion and altered metabolism. ${ }^{32,33}$

Our final study sample consisted of 318 mothers to ASD cases and 429 mothers to control individuals. Mothers to individuals in the final study sample were generally similar to the source population, though they tended to be older, have higher educational level, be of higher socioeconomic status, and were less likely to be born in Asia or Africa (Supplementary Table 1). Ethical approval was obtained by the Stockholm regional review board (DNR 2011/695-31/2, amendment 2012/706-32). Individual consent was not required for this anonymized register-based study.

\section{Case Ascertainment}

The case-finding procedure has been described previously. ${ }^{30,31}$ We considered any ASD diagnosis as an outcome (regardless of comorbidities) and also stratified the outcomes as ASD only (without comorbid ID or ADHD), ASD with ID, and ASD with ADHD. Individuals with both comorbid ID and ADHD were included in the ASD with ID group.

\section{Laboratory Analysis}

Serum aliquots were stored at $-80^{\circ} \mathrm{C}$ until analysis. After thawing on ice, samples were diluted 1:10,000 for analysis of $\alpha-2$-macroglobulin (A2M), haptoglobin (HAP), CRP and serum amyloid P (SAP), or 1:100 for analysis of ferritin (FER), fibrinogen (FIB), procalcitonin (PCT), serum amyloid $A$ (SAA) and tissue plasminogen activator (tPA). Samples from cases and controls were assigned 
medRxiv preprint doi: https://doi.org/10.1101/2021.03.03.21252813; this version posted March 5, 2021. The copyright holder for this preprint (which was not certified by peer review) is the author/funder, who has granted medRxiv a license to display the preprint in perpetuity.

It is made available under a CC-BY-NC-ND 4.0 International license.

randomly to 96-well assay plates for analysis using commercially available premixed, multiplex panels and the Bio-Plex 200 System (Bio-Rad, Hercules, CA, USA).

The average coefficient of variation for manufacture-provided control samples over the 13 assay plates was 18.6\% (Supplementary Table 2). Values below the lower limit of quantitation (LLOQ) were assigned a value of LLOQ $/ \sqrt{2}$. Values above the upper limit of quantitation (ULOQ) were assigned a value of ULOQ $\times 1.1$. HAP had a large proportion of imputed values $(75.77 \%)$, with the majority above the ULOQ, and was therefore excluded from the final analysis.

\section{Covariates}

Covariates considered as potential confounders were chosen on the basis of previously described relationships with ASD and plausibility of a potential relationship to APP: maternal age, psychiatric history, BMI, region of birth, education, and smoking at first antenatal visit; fetal sex; birth order; family income; and gestational week and season at serum sample. Covariates were extracted from the Medical Birth Register and the National Patient Register. Sociodemographic data were extracted from the Integrated Database for Labor Market Research.

\section{Statistical Analysis}

The concentrations of APP were log-transformed to normalize the distributions (Supplementary Figure 2A). To reduce the influence of assay plate-to-plate variation, we calculated standardized plate-based z-scores by subtracting the plate-specific mean concentration from each measurement and dividing by the plate-specific standard deviation (Supplementary Figure 2B). The standardized scores were then categorized into tertiles based on the distribution among controls (Supplementary Figure 2C).

Covariates were tested for association with the z-scores of each APP among cases and controls separately. We conducted linear regression analyses with the covariates as the independent variable and each APP as outcome variables, followed by a joint Wald-test to examine if the categories of the covariates were associated with different mean levels of APP. Covariates were included in the adjusted models if even weakly associated $(p<0.2)$ with at least one of the APP among the randomlysampled control population and with any of the outcomes. The final adjusted model included sex; birth order; family income quintile; maternal BMI, psychiatric history, region of origin, and age. 
medRxiv preprint doi: https://doi.org/10.1101/2021.03.03.21252813; this version posted March 5, 2021. The copyright holder for this preprint (which was not certified by peer review) is the author/funder, who has granted medRxiv a license to display the preprint in perpetuity.

It is made available under a CC-BY-NC-ND 4.0 International license.

In the categorical analyses, we used logistic regression models to estimate the odds of ASD associated with the different APP, using the middle tertile as the referent and followed by a Wald-test for the association between each APP and odds of ASD. For continuous analyses, we used restricted cubic spline models with three knots and a $z$-score $=0$ as the referent. To examine the overall association each APP with odds of ASD, we tested if all spline terms jointly were equal to zero using the Wald test. We investigated evidence for potential non-linearity by testing if all spline terms that would indicate a change in the direction of the relationship were equal to zero.

We conducted sensitivity analyses by restricting the cohort to the sample of Nordic-born mothers, as maternal region of origin was strongly associated with some APP and also with the likelihood of a child receiving an ASD with ID diagnosis. The non-Nordic group ( $n=81)$ was too small to evaluate on its own. In a separate sensitivity analysis, we adjusted additionally for annual quarter (season) at serum sampling and gestational week at serum sampling, factors that were not associated with ASD, but with plausible influence on APP levels.

\section{Results}

\section{Association of covariates with case status}

As expected, ASD-cases were more likely to be male and firstborn (Table 1). Mothers to ASD-cases were more likely to be older, have a history of psychiatric illness, and have lower family income levels, and were less likely to have a normal BMI, compared with mothers to unaffected controls. Mothers born in Africa and Asia were overrepresented among children with ASD and co-morbid ID.

\section{Association of APP with each other and with covariates}

Among mothers to unaffected controls, 14 of the 28 possible pairwise combinations of maternal APP (Supplementary Figure 3) were positively correlated at a significance level $p<0.05$, with the strongest correlations observed between CRP and A2M; CRP and SAP; A2M and SAP; and IPA and PCT.

Associations $(p<0.2)$ with at least one APP were seen for all covariates except serum sampling quarter in mothers to unaffected individuals (Figure 1, Supplementary Table 3). Maternal BMI was among the strongest predictors of APP levels. Similarly, among mothers to ASD-affected individuals, all covariates were associated $(p<0.1)$ with at least one APP, except sex and maternal age (Supplementary Figure 4, Supplementary Table 4). 
medRxiv preprint doi: https://doi.org/10.1101/2021.03.03.21252813; this version posted March 5, 2021. The copyright holder for this preprint (which was not certified by peer review) is the author/funder, who has granted medRxiv a license to display the preprint in perpetuity.

It is made available under a CC-BY-NC-ND 4.0 International license.

\section{Association of APP with odds of ASD}

Compared with ASD-unaffected controls, there were no significant differences in median levels of APP in mothers to ASD-affected individuals, though there was a reduction $(p<0.05)$ in CRP among mothers to offspring with ASD only (Table1, Supplementary Figure 5).

In the unadjusted regression analysis of APP tertiles, we observed a trend towards a u-shaped association ( $p=0.06$ ) between FER and odds of any ASD (Supplementary Figure 6), with a similar ushaped pattern present for the stratified outcome ASD with ID $(p<0.01)$ but absent for the other stratified outcomes. The lowest tertile of CRP was associated with increased odds of ASD only $(p<0.01)$.

In fully adjusted models, the association between FER and any ASD was strengthened with increased odds of $A S D$ in the lowest $(\mathrm{OR}=1.82,95 \% \mathrm{Cl} 1.19-2.78)$ and highest $(1.74,1.16-2.60)$ tertiles compared to the middle tertile (Figure 2). The association between FER and odds of ASD with ID was somewhat attenuated, with increased odds of ASD with ID for the lowest $(3.58,1.79-7.17)$ and highest (3.20, 1.62-6.29) tertiles. The association between CRP and odds of ASD only was attenuated, although with increased odds for the lowest tertile compared to the middle tertile $(2.15,1.17-3.93)$. In adjusted cubic spline models, we observed evidence for non-linear relationships between z-scores of maternal CRP, FER and SAA and the outcomes (Supplementary Table 5). As in the categorical models, we observed a u-shaped relationship between FER and any ASD $(p=0.08)$ as well as ASD with ID ( $p=0.05$; Figure 3 , Supplementary Figure 7 ). The overall pattern of association between CRP and odds of ASD only, with higher odds at lower concentrations, was similar to the categorical analysis, although it did not reach statistical significance $(p=0.35)$ (Supplementary Figure 8). A ushaped pattern of association was observed between maternal CRP $(p=0.06)$ and SAP $(p=0.03)$ and odds of ASD with ADHD (Supplementary Figure 9), with the strongest associations above the mean.

\section{Sensitivity analyses}

The estimates observed in the sensitivity analyses, either restricting to Nordic-born mothers or considering factors that might influence APP-levels, were similar to those observed in the main analyses (Supplementary Figure 10, Supplementary Figure 11).

\section{Discussion}


medRxiv preprint doi: https://doi.org/10.1101/2021.03.03.21252813; this version posted March 5, 2021. The copyright holder for this preprint (which was not certified by peer review) is the author/funder, who has granted medRxiv a license to display the preprint in perpetuity.

It is made available under a CC-BY-NC-ND 4.0 International license.

In this population-based cohort of pregnant women, we measured a range of immune markers to assess the possible link between innate immune activation in early pregnancy and subsequent ASD in offspring. Overall, we found no strong evidence for elevated APP being associated with increased odds of ASD regardless of comorbidities. However, we did observe that low levels of CRP were associated with increased odds of ASD without ID or ADHD, with some analyses suggesting that higher levels of CRP and SAP are associated with higher risk of ASD with ADHD. We also found that both low and high levels of FER were associated with increased odds of ASD, particularly ASD with ID.

\section{Comparison with previous studies}

There are four previous studies investigating maternal APP and risk of ASD in offspring, all measuring the acute phase reactant CRP.

In a study by Brown et. al, ${ }^{26}$ the highest quintile of gestational CRP in first and early second trimester was associated with increased odds for autism, and a positive association was apparent when CRP was treated as a continuous variable. The prevalence of ASD in that study $(1,132$ cases of childhood autism in a birth cohort of 1.2 million, or $0.094 \%$ ) stands in contrast to the present study, where we included all ICD and DSM-IV autistic diagnoses, with a joint prevalence of 1.52\%. Furthermore, we were able to control for a larger number of health- and sociodemographic covariates, such as BMI and socioeconomic status, which may also contribute to the discrepancy in the results.

In a recent study by Egorova et al., 62 biomarkers including CRP were measured in serum samples (gestational week 14) of 100 mothers to ASD cases and 100 unaffected controls. ${ }^{29}$ No significant associations with CRP were found, though this smaller study had decreased power to detect differences. Also, CRP was treated as a linear continuous variable, in contrast to the present study where we allowed for non-linear relationships.

Koks et al. reported an association between maternal CRP (measured before 18 weeks of gestation) and autistic traits in offspring at age 6, as measured by the continuous Social Responsiveness Scale in the Generation $\mathrm{R}$ cohort study. ${ }^{28}$ The association was completely attenuated after controlling for maternal health-related factors and socioeconomic covariates, stressing the importance of controlling for such parameters. 
medRxiv preprint doi: https://doi.org/10.1101/2021.03.03.21252813; this version posted March 5, 2021. The copyright holder for this preprint (which was not certified by peer review) is the author/funder, who has granted medRxiv a license to display the preprint in perpetuity.

It is made available under a CC-BY-NC-ND 4.0 International license.

In the Californian Early Markers for Autism (EMA) case-control study, the third and fourth quartiles of CRP (at 15-19 weeks of gestation) compared to the lowest quartile were associated with a decreased risk of ASD, ${ }^{27}$ which is in general agreement with our current findings. The definition and prevalence of the outcome were similar, as were the regression models with respect to covariates included.

Interpretation and potential mechanisms

\section{Maternal APP and risk for ASD}

Baseline concentrations of APP are influenced by both genetic and environmental factors. Previous studies have estimated heritability coefficients in adults for FIB (27-51\%), tPA (23\%-27\%), and CRP (10-65\%), with estimates from a longitudinal twin study at around 50\% for CRP, with stability over time. ${ }^{34-36}$

We observed evidence of moderate to high pairwise correlations between several of the APP, possibly reflecting shared regulation. However, many of the observed relationships were weak or non-existent, implying partially independent modes of regulation or biological function, in line with previous knowledge of the APP. ${ }^{22}$ In general, lower correlations were observed among APPs in maternal serum compared to those observed in neonatal samples. ${ }^{31}$ In accordance with previous evidence, ${ }^{37}$ we observed a strong correlation between maternal BMI and CRP, with overweight and obesity being associated with elevated levels.

Several immune proteins have dual roles, including a role as modulators of neurodevelopment. Animal models and observational studies suggest a harmful effect of maternal infections during pregnancy on the developing fetal brain, not only of pathogenic (teratogenic) microorganisms themselves, but also an effect of maternal inflammatory mediators crossing the fetal-placental barrier. 9,10 This is often referred to as the maternal immune activation hypothesis of ASD. Based on the eight APP studied here, we found no convincing general trend of maternal immune activation early in ASD pregnancies. On the contrary, low levels of CRP were associated with increased odds of ASD without ID or ADHD. We also observed a borderline association between increased odds of ASD with ID and low levels of SAA, an APP with secretion kinetics resembling those of CRP. ${ }^{38}$ 
medRxiv preprint doi: https://doi.org/10.1101/2021.03.03.21252813; this version posted March 5, 2021. The copyright holder for this preprint (which was not certified by peer review) is the author/funder, who has granted medRxiv a license to display the preprint in perpetuity.

It is made available under a CC-BY-NC-ND 4.0 International license .

CRP is a member of the pentraxin family, synthesized in hepatocytes as a response to proinflammatory cytokines, particularly Interleukin-6, and to a lesser degree Interleukin-1 and Tumor Necrosis Factor- $\alpha .{ }^{39}$ It opsonizes common molecular patterns on the surface of pathogens and induces complement activation. ${ }^{36}$

Evidence of an association between low levels of maternal CRP and increased odds of ASD are now apparent in two large case-control/cohort studies of similar design. ${ }^{27}$ In schizophrenia, another complex neuropsychiatric disorder sharing common genetic variation, and brain transcriptional dysregulation with autism, ${ }^{40,41}$ genetic loci associated with high levels of CRP have been found protective in Mendelian randomization studies. ${ }^{42}$ This is in alignment with a previous observational study of several neonatal APP and risk of non-affective psychotic disorders in adulthood. ${ }^{43}$ In our case-cohort study of neonatal APP measured in dried blood spots, we observed a u-shaped association between CRP and odds of ASD. ${ }^{31}$

It is not clear how low levels of maternal CRP in first trimester might influence the risk of ASD in offspring. Considering the opsonizing and complement activating functions of CRP, low levels might represent a suboptimal innate immune effector function. Further, low levels of CRP in the first trimester do not exclude maternal or fetal immune activation later in pregnancy, and the low concentrations early in pregnancy might influence risk of serious infections later on. ${ }^{31}$

\section{Ferritin and $A S D$}

Serum FER is a sensitive marker of total body iron not bound to hemoglobin. ${ }^{44}$ There is increasing evidence concerning the importance of iron metabolism for early neurodevelopment. ${ }^{45}$ Apart from serving as oxygen transporter, iron functions as a cofactor in cytochrome reactions generating ATP and in enzymes involved in neuronal myelinization..$^{46-48}$ In an observational study, Schmidt et al. reported an association between self-reported low maternal iron intake prior to and during pregnancy and risk of autism in the offspring. ${ }^{49}$ Maternal iron deficiency is the most common cause of anemia, and the latter is associated with several adverse birth-related and behavioral outcomes in the offspring, including small for gestational age, ASD, ADHD and ID. ${ }^{14,50,51}$ Low FER levels in neonates have been associated with adverse neurocognitive and behavioral outcomes. ${ }^{52-54}$ In our previous case-cohort study of neonatal APP, we observed an increased risk of ASD with lower levels of FER if 
medRxiv preprint doi: https://doi.org/10.1101/2021.03.03.21252813; this version posted March 5, 2021. The copyright holder for this preprint (which was not certified by peer review) is the author/funder, who has granted medRxiv a license to display the preprint in perpetuity.

It is made available under a CC-BY-NC-ND 4.0 International license.

mothers had anemia during gestation. ${ }^{31}$ In a separate discordant sibling-comparison, levels of FER below the mean were strongly associated with increased odds of ASD.

While low levels of FER are specific for iron deficiency, high levels are harder to interpret, since they can be a consequence iron overload or elevated as part of the acute phase response. ${ }^{23}$ If a consequence of iron-overload, high levels of FER might indicate increased levels of circulating nonbound iron that may in turn lead to oxidative stress and DNA damage and affect the maternalplacental-fetal unit. ${ }^{55,56}$ There is evidence of u-shaped associations between maternal hemoglobin and FER levels with obstetric outcomes, such as low birth weight. ${ }^{51}$ The increase in FER may also represent increased innate immune activity. The hypoferraemia due to increased concentrations of iron chaperones, such as FER, induced by inflammation is important in the host defense against infection by sequestering iron from pathogens. ${ }^{57}$ However, we did not detect any risk associated with high levels of any of the other APP studied to indicate an ongoing increase in innate immune activity.

\section{Strengths and weaknesses}

By measuring a range of proteins involved in the maternal innate immune defense in a large population-based cohort, we aimed to increase the likelihood of picking up any signal of maternal immune activation. Further, due to the pleiotropic physiological roles of most APP, we also had the possibility to investigate other pathophysiological processes, not necessarily directly related to immune functioning. We used a validated case-finding procedure ${ }^{30}$ and a broad range of register data to control for health- and sociodemographic confounders.

Although the sample size is large, it may be underpowered to detect subtle associations, and the number of individuals included in our analyses of the stratified outcomes was particularly limited. Further, although it can be considered a strength to include many immune markers, we also make multiple statistical comparisons, increasing the probability of chance findings. We only have a single measurement at one time-point in pregnancy, restricted to samples drawn in the first trimester for the purpose of interpretability. Consequently, we cannot draw conclusions regarding these markers in later trimesters. By restricting to samples drawn in the first trimester, we excluded a larger proportion of migrant women and women from low-income families. However, a separate sensitivity analysis stratifying the sample on maternal region of birth did not change the estimates. Further, since this is an observational study, we cannot give the results a causal interpretation. Although we adjust for a large 
medRxiv preprint doi: https://doi.org/10.1101/2021.03.03.21252813; this version posted March 5, 2021. The copyright holder for this preprint (which was not certified by peer review) is the author/funder, who has granted medRxiv a license to display the preprint in perpetuity.

It is made available under a CC-BY-NC-ND 4.0 International license .

number of covariates, there is still the possibility the results are influenced by residual confounding. Finally, the coefficient of variation was markedly higher for PCT compared to the other analytes, and thus the results for PCT must be interpreted with caution.

\section{Conclusion}

We investigated associations between eight maternal inflammatory proteins in first trimester of pregnancy and risk of ASD in offspring. We observed increased odds of ASD without ID or ADHD in offspring of mothers with low levels of CRP, though the biological mechanism underlying this relationship remains unclear. We also observed increased odds of any ASD, and particularly ASD with ID, in offspring of mothers with both low and elevated levels of ferritin. Our results give no strong support for the maternal immune activation hypothesis, but rather suggest that low maternal innate immune activity is associated with adverse neurodevelopmental outcomes. Our results also add evidence to a plausibly important role of iron metabolism during early neurodevelopment. Future studies ought to investigate the causes of low CRP levels in early pregnancy and how these relate to ASD risk in the offspring, and consider measurements of additional biomarkers of iron status to improve our understanding of the relationship between FER and ASD/ID.

\section{Acknowledgements}

This work was supported by grants from the Swedish Research Council (grant numbers 2016-01477, 2012-2264, 523-2010-1052 [to CD], grant number 2017-02900 [to RG]) and the Stanley Medical Research Institute (to HK). The funders had no role in the design and conduct of the study; collection, management, analysis, and interpretation of the data; preparation, review, or approval of the manuscript; or decision to submit the manuscript for publication.

\section{Disclosures}

The authors report no potential conflicts of interest. 
medRxiv preprint doi: https://doi.org/10.1101/2021.03.03.21252813; this version posted March 5, 2021. The copyright holder for this preprint (which was not certified by peer review) is the author/funder, who has granted medRxiv a license to display the preprint in perpetuity.

It is made available under a CC-BY-NC-ND 4.0 International license .

\section{References}

1. Lyall K, Croen L, Daniels J, Fallin MD, Ladd-Acosta C, Lee BK et al. The Changing Epidemiology of Autism Spectrum Disorders. Annual review of public health 2017; 38: 81-102.

2. Lord C, Elsabbagh M, Baird G, Veenstra-Vanderweele J. Autism spectrum disorder. Lancet (London, England) 2018; 392(10146): 508-520.

3. Lai MC, Kassee C, Besney R, Bonato S, Hull L, Mandy W et al. Prevalence of co-occurring mental health diagnoses in the autism population: a systematic review and meta-analysis. Lancet Psychiatry 2019; 6(10): 819-829.

4. Xie S, Karlsson H, Dalman C, Widman L, Rai D, Gardner RM et al. The Familial Risk of Autism Spectrum Disorder with and without Intellectual Disability. Autism research : official journal of the International Society for Autism Research 2020.

5. Saghazadeh A, Ataeinia B, Keynejad K, Abdolalizadeh A, Hirbod-Mobarakeh A, Rezaei N. A meta-analysis of pro-inflammatory cytokines in autism spectrum disorders: Effects of age, gender, and latitude. J Psychiatr Res 2019; 115: 90-102.

6. Deverman BE, Patterson PH. Cytokines and CNS development. Neuron 2009; 64(1): 61-78.

7. Boulanger LM. Immune proteins in brain development and synaptic plasticity. Neuron 2009; 64(1): 93-109.

8. Onore C, Careaga M, Ashwood P. The role of immune dysfunction in the pathophysiology of autism. Brain Behav Immun 2012; 26(3): 383-392.

9. Careaga M, Murai T, Bauman MD. Maternal Immune Activation and Autism Spectrum Disorder: From Rodents to Nonhuman and Human Primates. Biol Psychiatry 2017; 81(5): 391401.

10. Ji-Xu A, Vincent A. Maternal Immunity in Autism Spectrum Disorders: Questions of Causality, Validity, and Specificity. Journal of clinical medicine 2020; 9(8).

11. Chen SW, Zhong XS, Jiang LN, Zheng XY, Xiong YQ, Ma SJ et al. Maternal autoimmune diseases and the risk of autism spectrum disorders in offspring: A systematic review and meta-analysis. Behavioural brain research 2016; 296: 61-69.

12. Lei XY, Li YJ, Ou JJ, Li YM. Association between parental body mass index and autism spectrum disorder: a systematic review and meta-analysis. European child \& adolescent psychiatry 2019; 28(7): 933-947. 
medRxiv preprint doi: https://doi.org/10.1101/2021.03.03.21252813; this version posted March 5, 2021. The copyright holder for this preprint (which was not certified by peer review) is the author/funder, who has granted medRxiv a license to display the preprint in perpetuity.

It is made available under a CC-BY-NC-ND 4.0 International license.

13. Jiang HY, Xu LL, Shao L, Xia RM, Yu ZH, Ling ZX et al. Maternal infection during pregnancy and risk of autism spectrum disorders: A systematic review and meta-analysis. Brain Behav Immun 2016; 58: 165-172.

14. Wiegersma AM, Dalman C, Lee BK, Karlsson H, Gardner RM. Association of Prenatal Maternal Anemia With Neurodevelopmental Disorders. JAMA Psychiatry 2019: 1-12.

15. Lee BK, Eyles DW, Magnusson C, Newschaffer CJ, McGrath JJ, Kvaskoff D et al.

Developmental vitamin $D$ and autism spectrum disorders: findings from the Stockholm Youth Cohort. Mol Psychiatry 2019.

16. Yip BHK, Bai D, Mahjani B, Klei L, Pawitan Y, Hultman CM et al. Heritable Variation, With Little or No Maternal Effect, Accounts for Recurrence Risk to Autism Spectrum Disorder in Sweden. Biol Psychiatry 2018; 83(7): 589-597.

17. Gardner RM, Lee BK, Magnusson C, Rai D, Frisell T, Karlsson $\mathrm{H}$ et al. Maternal body mass index during early pregnancy, gestational weight gain, and risk of autism spectrum disorders: Results from a Swedish total population and discordant sibling study. Int J Epidemiol 2015; 44(3): 870-883.

18. Tylee DS, Sun J, Hess JL, Tahir MA, Sharma E, Malik R et al. Genetic correlations among psychiatric and immune-related phenotypes based on genome-wide association data. American journal of medical genetics Part B, Neuropsychiatric genetics : the official publication of the International Society of Psychiatric Genetics 2018; 177(7): 641-657.

19. Jones KL, Croen LA, Yoshida CK, Heuer L, Hansen R, Zerbo O et al. Autism with intellectual disability is associated with increased levels of maternal cytokines and chemokines during gestation. Mol Psychiatry 2016.

20. Krakowiak P, Goines PE, Tancredi DJ, Ashwood P, Hansen RL, Hertz-Picciotto I et al. Neonatal Cytokine Profiles Associated with Autism Spectrum Disorder. Biol Psychiatry 2015.

21. Abdallah MW, Larsen N, Mortensen EL, Atladottir HO, Norgaard-Pedersen B, BonefeldJorgensen EC et al. Neonatal levels of cytokines and risk of autism spectrum disorders: an exploratory register-based historic birth cohort study utilizing the Danish Newborn Screening Biobank. Journal of neuroimmunology 2012; 252(1-2): 75-82.

22. Gabay C, Kushner I. Acute-phase proteins and other systemic responses to inflammation. The New England journal of medicine 1999; 340(6): 448-454.

23. Wang W, Knovich MA, Coffman LG, Torti FM, Torti SV. Serum ferritin: Past, present and future. Biochimica et biophysica acta 2010; 1800(8): 760-769.

24. Mosesson MW. Fibrinogen and fibrin structure and functions. J Thromb Haemost 2005; 3(8): 1894-1904. 
medRxiv preprint doi: https://doi.org/10.1101/2021.03.03.21252813; this version posted March 5, 2021. The copyright holder for this preprint (which was not certified by peer review) is the author/funder, who has granted medRxiv a license to display the preprint in perpetuity.

It is made available under a CC-BY-NC-ND 4.0 International license.

25. Sack GH, Jr. Serum amyloid A - a review. Mol Med 2018; 24(1): 46.

26. Brown AS, Sourander A, Hinkka-Yli-Salomäki S, McKeague IW, Sundvall J, Surcel HM. Elevated maternal C-reactive protein and autism in a national birth cohort. Mol Psychiatry 2014; 19(2): 259-264.

27. Zerbo O, Traglia M, Yoshida C, Heuer LS, Ashwood P, Delorenze GN et al. Maternal midpregnancy $\mathrm{C}$-reactive protein and risk of autism spectrum disorders: the early markers for autism study. Translational psychiatry 2016; 6(4): e783.

28. Koks N, Ghassabian A, Greaves-Lord K, Hofman A, Jaddoe VW, Verhulst FC et al. Maternal CReactive Protein Concentration in Early Pregnancy and Child Autistic Traits in the General Population. Paediatr Perinat Epidemiol 2016; 30(2): 181-189.

29. Egorova O, Myte R, Schneede J, Hägglöf B, Bölte S, Domellöf E et al. Maternal blood folate status during early pregnancy and occurrence of autism spectrum disorder in offspring: a study of 62 serum biomarkers. Molecular autism 2020; 11(1): 7.

30. Idring S, Rai D, Dal H, Dalman C, Sturm H, Zander E et al. Autism spectrum disorders in the Stockholm Youth Cohort: design, prevalence and validity. PloS one 2012; 7(7): e41280.

31. Gardner RM, Lee BK, Brynge M, Sjöqvist H, Dalman C, Karlsson H. Neonatal Levels of Acute Phase Proteins and Risk of Autism Spectrum Disorder. Biol Psychiatry 2020.

32. Haram K, Augensen K, Elsayed S. Serum protein pattern in normal pregnancy with special reference to acute-phase reactants. British journal of obstetrics and gynaecology 1983; 90(2): 139-145.

33. Kalhan SC. Protein metabolism in pregnancy. The American Journal of Clinical Nutrition 2000; 71(5): 1249S-1255S.

34. Freeman MS, Mansfield MW, Barrett JH, Grant PJ. Genetic contribution to circulating levels of hemostatic factors in healthy families with effects of known genetic polymorphisms on heritability. Arteriosclerosis, thrombosis, and vascular biology 2002; 22(3): 506-510.

35. Souto JC, Almasy L, Borrell M, Garí M, Martínez E, Mateo J et al. Genetic determinants of hemostasis phenotypes in Spanish families. Circulation 2000; 101(13): 1546-1551.

36. Sas AA, Vaez A, Jamshidi Y, Nolte IM, Kamali Z, T DS et al. Genetic and environmental influences on stability and change in baseline levels of C-reactive protein: A longitudinal twin study. Atherosclerosis 2017; 265: 172-178. 
medRxiv preprint doi: https://doi.org/10.1101/2021.03.03.21252813; this version posted March 5, 2021. The copyright holder for this preprint (which was not certified by peer review) is the author/funder, who has granted medRxiv a license to display the preprint in perpetuity.

It is made available under a CC-BY-NC-ND 4.0 International license .

37. Choi J, Joseph L, Pilote L. Obesity and C-reactive protein in various populations: a systematic review and meta-analysis. Obesity reviews : an official journal of the International Association for the Study of Obesity 2013; 14(3): 232-244.

38. Malle E, Steinmetz A, Raynes JG. Serum amyloid A (SAA): an acute phase protein and apolipoprotein. Atherosclerosis 1993; 102(2): 131-146.

39. Sproston NR, Ashworth JJ. Role of C-Reactive Protein at Sites of Inflammation and Infection. Front Immunol 2018; 9: 754.

40. Gandal MJ, Haney JR, Parikshak NN, Leppa V, Ramaswami G, Hartl C et al. Shared molecular neuropathology across major psychiatric disorders parallels polygenic overlap. Science 2018; 359(6376): 693-697.

41. Meta-analysis of GWAS of over 16,000 individuals with autism spectrum disorder highlights a novel locus at 10q24.32 and a significant overlap with schizophrenia. Molecular autism 2017; 8: 21.

42. Ligthart S, Vaez A, Vosa U, Stathopoulou MG, de Vries PS, Prins BP et al. Genome Analyses of $>200,000$ Individuals Identify 58 Loci for Chronic Inflammation and Highlight Pathways that Link Inflammation and Complex Disorders. Am J Hum Genet 2018; 103(5): 691-706.

43. Gardner RM, Dalman C, Wicks S, Lee BK, Karlsson H. Neonatal levels of acute phase proteins and later risk of non-affective psychosis. Translational psychiatry 2013; 3: e228.

44. Lopez A, Cacoub P, Macdougall IC, Peyrin-Biroulet L. Iron deficiency anaemia. Lancet (London, England) 2016; 387(10021): 907-916.

45. Georgieff MK. Iron deficiency in pregnancy. American journal of obstetrics and gynecology 2020; 223(4): 516-524.

46. Bastian TW, von Hohenberg WC, Mickelson DJ, Lanier LM, Georgieff MK. Iron Deficiency Impairs Developing Hippocampal Neuron Gene Expression, Energy Metabolism, and Dendrite Complexity. Developmental neuroscience 2016; 38(4): 264-276.

47. Ortiz E, Pasquini JM, Thompson K, Felt B, Butkus G, Beard J et al. Effect of manipulation of iron storage, transport, or availability on myelin composition and brain iron content in three different animal models. Journal of neuroscience research 2004; 77(5): 681-689.

48. Brunette KE, Tran PV, Wobken JD, Carlson ES, Georgieff MK. Gestational and neonatal iron deficiency alters apical dendrite structure of CA1 pyramidal neurons in adult rat hippocampus. Developmental neuroscience 2010; 32(3): 238-248. 
medRxiv preprint doi: https://doi.org/10.1101/2021.03.03.21252813; this version posted March 5, 2021. The copyright holder for this preprint (which was not certified by peer review) is the author/funder, who has granted medRxiv a license to display the preprint in perpetuity.

It is made available under a CC-BY-NC-ND 4.0 International license .

49. Schmidt RJ, Tancredi DJ, Krakowiak P, Hansen RL, Ozonoff S. Maternal intake of supplemental iron and risk of autism spectrum disorder. American journal of epidemiology 2014; 180(9): 890-900.

50. Rahman MM, Abe SK, Rahman MS, Kanda M, Narita S, Bilano V et al. Maternal anemia and risk of adverse birth and health outcomes in low- and middle-income countries: systematic review and meta-analysis. Am J Clin Nutr 2016; 103(2): 495-504.

51. Dewey KG, Oaks BM. U-shaped curve for risk associated with maternal hemoglobin, iron status, or iron supplementation. Am J Clin Nutr 2017; 106(Suppl 6): 1694s-1702s.

52. Siddappa AM, Georgieff MK, Wewerka S, Worwa C, Nelson CA, Deregnier RA. Iron deficiency alters auditory recognition memory in newborn infants of diabetic mothers. Pediatric research 2004; 55(6): 1034-1041.

53. Geng F, Mai X, Zhan J, Xu L, Zhao Z, Georgieff M et al. Impact of Fetal-Neonatal Iron Deficiency on Recognition Memory at 2 Months of Age. The Journal of pediatrics 2015; 167(6): 1226-1232.

54. Tamura T, Goldenberg RL, Hou J, Johnston KE, Cliver SP, Ramey SL et al. Cord serum ferritin concentrations and mental and psychomotor development of children at five years of age. The Journal of pediatrics 2002; 140(2): 165-170.

55. Steer P, Alam MA, Wadsworth J, Welch A. Relation between maternal haemoglobin concentration and birth weight in different ethnic groups. BMJ (Clinical research ed) 1995; 310(6978): 489-491.

56. Casanueva E, Viteri FE. Iron and oxidative stress in pregnancy. The Journal of nutrition 2003; 133(5 Suppl 2): 1700s-1708s.

57. Drakesmith $\mathrm{H}$, Prentice AM. Hepcidin and the iron-infection axis. Science 2012; 338(6108): 768-772. 
medRxiv preprint doi: https://doi.org/10.1101/2021.03.03.21252813; this version posted March 5, 2021. The copyright holder for this preprint (which was not certified by peer review) is the author/funder, who has granted medRxiv a license to display the preprint in perpetuity.

It is made available under a CC-BY-NC-ND 4.0 International license.

Table 1. Characteristics of individuals diagnosed with ASD and unaffected individuals in the study sample.

\begin{tabular}{|c|c|c|c|c|c|c|c|}
\hline & $\begin{array}{l}\text { Unaffected } \\
(n=429)\end{array}$ & $\begin{array}{l}\text { ASD } \\
(n=318)\end{array}$ & $\begin{array}{l}\text { p- } \\
\text { value }^{1}\end{array}$ & $\begin{array}{l}\text { ASD only } \\
(n=100)\end{array}$ & $\begin{array}{l}\text { ASD with } \\
\text { ID } \\
(\mathrm{n}=101)\end{array}$ & $\begin{array}{l}\text { ASD with } \\
\text { ADHD } \\
\text { (n=117) }\end{array}$ & $\begin{array}{l}\text { p- } \\
\text { value }\end{array}$ \\
\hline \multicolumn{8}{|l|}{ Sex } \\
\hline Female & $\begin{array}{l}204 \\
(47.6 \%)\end{array}$ & $69(21.7 \%)$ & $<0.001$ & $19(19.0 \%)$ & $27(26.7 \%)$ & $23(19.7 \%)$ & $<0.001$ \\
\hline Male & $\begin{array}{l}225 \\
(52.4 \%)\end{array}$ & $\begin{array}{l}249 \\
(78.3 \%)\end{array}$ & & $81(81.0 \%)$ & $74(73.3 \%)$ & $94(80.3 \%)$ & \\
\hline \multicolumn{8}{|l|}{ Birth Order } \\
\hline 1st born & $\begin{array}{l}178 \\
(41.5 \%)\end{array}$ & $\begin{array}{l}158 \\
(49.7 \%)\end{array}$ & 0.061 & $55(55.0 \%)$ & $38(37.6 \%)$ & $65(55.6 \%)$ & 0.011 \\
\hline 2nd born & $\begin{array}{l}160 \\
(37.3 \%)\end{array}$ & $\begin{array}{l}105 \\
(33.0 \%)\end{array}$ & & $30(30.0 \%)$ & $45(44.6 \%)$ & $30(25.6 \%)$ & \\
\hline $\begin{array}{l}\text { 3rd or } \\
\text { higher }\end{array}$ & $74(17.2 \%)$ & $42(13.2 \%)$ & & $12(12.0 \%)$ & $15(14.9 \%)$ & $15(12.8 \%)$ & \\
\hline Missing & $17(4.0 \%)$ & $13(4.1 \%)$ & & $3(3.0 \%)$ & $3(3.0 \%)$ & $7(6.0 \%)$ & \\
\hline \multicolumn{8}{|c|}{ Maternal Age (Years) } \\
\hline$<25$ & $43(10.0 \%)$ & $38(11.9 \%)$ & 0.041 & $8(8.0 \%)$ & $12(11.9 \%)$ & $18(15.4 \%)$ & 0.054 \\
\hline $25-29$ & $\begin{array}{l}108 \\
(25.2 \%)\end{array}$ & $\begin{array}{l}101 \\
(31.8 \%)\end{array}$ & & $29(29.0 \%)$ & $27(26.7 \%)$ & $45(38.5 \%)$ & \\
\hline 30-34 & $\begin{array}{l}178 \\
(41.5 \%)\end{array}$ & $\begin{array}{l}101 \\
(31.8 \%)\end{array}$ & & $34(34.0 \%)$ & $37(36.6 \%)$ & $30(25.6 \%)$ & \\
\hline $35-39$ & $89(20.7 \%)$ & $64(20.1 \%)$ & & $24(24.0 \%)$ & $19(18.8 \%)$ & $21(17.9 \%)$ & \\
\hline$\geq 40$ & $11(2.6 \%)$ & $14(4.4 \%)$ & & $5(5.0 \%)$ & $6(5.9 \%)$ & $3(2.6 \%)$ & \\
\hline \multicolumn{8}{|c|}{ Maternal Psychiatric History } \\
\hline No & $\begin{array}{l}289 \\
(67.4 \%)\end{array}$ & $\begin{array}{l}162 \\
(50.9 \%)\end{array}$ & $<0.001$ & $50(50.0 \%)$ & $60(59.4 \%)$ & $52(44.4 \%)$ & $<0.001$ \\
\hline Yes & $\begin{array}{l}140 \\
(32.6 \%)\end{array}$ & $\begin{array}{l}156 \\
(49.1 \%)\end{array}$ & & $50(50.0 \%)$ & $41(40.6 \%)$ & $65(55.6 \%)$ & \\
\hline \multicolumn{8}{|c|}{ Maternal BMI } \\
\hline $\begin{array}{l}\text { Underweigh } \\
t\end{array}$ & $8(1.9 \%)$ & $7(2.2 \%)$ & 0.057 & $2(2.0 \%)$ & $3(3.0 \%)$ & $2(1.7 \%)$ & 0.005 \\
\hline Normal & $\begin{array}{l}213 \\
(49.7 \%)\end{array}$ & $\begin{array}{l}126 \\
(39.6 \%)\end{array}$ & & $49(49.0 \%)$ & $43(42.6 \%)$ & $34(29.1 \%)$ & \\
\hline Overweight & $59(13.8 \%)$ & $54(17.0 \%)$ & & $11(11.0 \%)$ & $18(17.8 \%)$ & $25(21.4 \%)$ & \\
\hline Obese & $16(3.7 \%)$ & $21(6.6 \%)$ & & $2(2.0 \%)$ & $6(5.9 \%)$ & $13(11.1 \%)$ & \\
\hline Missing & $\begin{array}{l}133 \\
(31.0 \%)\end{array}$ & $\begin{array}{l}110 \\
(34.6 \%)\end{array}$ & & $36(36.0 \%)$ & $31(30.7 \%)$ & $43(36.8 \%)$ & \\
\hline \multicolumn{8}{|c|}{ Maternal Country of Birth } \\
\hline Africa & $18(4.2 \%)$ & $16(5.0 \%)$ & 0.89 & $3(3.0 \%)$ & $12(11.9 \%)$ & $1(0.9 \%)$ & $<0.001$ \\
\hline Asia & $34(7.9 \%)$ & $27(8.5 \%)$ & & $8(8.0 \%)$ & $18(17.8 \%)$ & $1(0.9 \%)$ & \\
\hline Nordic & $\begin{array}{l}349 \\
(81.4 \%)\end{array}$ & $\begin{array}{l}250 \\
(78.6 \%)\end{array}$ & & $83(83.0 \%)$ & $61(60.4 \%)$ & $\begin{array}{l}106 \\
(90.6 \%)\end{array}$ & \\
\hline Other & $15(3.5 \%)$ & $12(3.8 \%)$ & & $4(4.0 \%)$ & $4(4.0 \%)$ & $4(3.4 \%)$ & \\
\hline $\begin{array}{l}\text { Other } \\
\text { Europe }\end{array}$ & $13(3.0 \%)$ & $13(4.1 \%)$ & & $2(2.0 \%)$ & $6(5.9 \%)$ & $5(4.3 \%)$ & \\
\hline \multicolumn{8}{|c|}{ Family Income Quintile } \\
\hline $1^{\text {st }}$ (Lowest) & $41(9.6 \%)$ & $39(12.3 \%)$ & 0.006 & $8(8.0 \%)$ & $22(21.8 \%)$ & $9(7.7 \%)$ & $<0.001$ \\
\hline $2^{\text {nd }}$ & $75(17.5 \%)$ & $81(25.5 \%)$ & & $20(20.0 \%)$ & $28(27.7 \%)$ & $33(28.2 \%)$ & \\
\hline $3^{\text {rd }}$ & $90(21.0 \%)$ & $64(20.1 \%)$ & & $22(22.0 \%)$ & $17(16.8 \%)$ & 25 (21.4\%) & \\
\hline
\end{tabular}


medRxiv preprint doi: https://doi.org/10.1101/2021.03.03.21252813; this version posted March 5, 2021. The copyright holder for this preprint (which was not certified by peer review) is the author/funder, who has granted medRxiv a license to display the preprint in perpetuity.

\begin{tabular}{|c|c|c|c|c|c|c|c|}
\hline $4^{\text {th }}$ & $\begin{array}{l}100 \\
(23.3 \%)\end{array}$ & $75(23.6 \%)$ & & $18(18.0 \%)$ & $23(22.8 \%)$ & $34(29.1 \%)$ & \\
\hline $5^{\text {th }}$ & $\begin{array}{l}123 \\
(28.7 \%)\end{array}$ & $59(18.6 \%)$ & & $32(32.0 \%)$ & $11(10.9 \%)$ & $16(13.7 \%)$ & \\
\hline \multicolumn{8}{|c|}{ Maternal Education at Birth } \\
\hline$<9$ years & $55(12.8 \%)$ & $42(13.2 \%)$ & 0.22 & $10(10.0 \%)$ & $13(12.9 \%)$ & $19(16.2 \%)$ & 0.14 \\
\hline $9-12$ years & $\begin{array}{l}179 \\
(41.7 \%)\end{array}$ & $\begin{array}{l}151 \\
(47.5 \%)\end{array}$ & & $41(41.0 \%)$ & $52(51.5 \%)$ & $58(49.6 \%)$ & \\
\hline$>12$ years & $\begin{array}{l}194 \\
(45.2 \%)\end{array}$ & $\begin{array}{l}124 \\
(39.0 \%)\end{array}$ & & $49(49.0 \%)$ & $35(34.7 \%)$ & $40(34.2 \%)$ & \\
\hline missing & $1(0.2 \%)$ & $1(0.3 \%)$ & & & $1(1.0 \%)$ & & \\
\hline \multicolumn{8}{|c|}{ Gestational Week at Serum Sample } \\
\hline$<10$ weeks & $\begin{array}{l}203 \\
(47.3 \%)\end{array}$ & $\begin{array}{l}160 \\
(50.3 \%)\end{array}$ & 0.42 & $52(52.0 \%)$ & $48(47.5 \%)$ & $60(51.3 \%)$ & 0.77 \\
\hline 10-13 weeks & $\begin{array}{l}226 \\
(52.7 \%)\end{array}$ & $\begin{array}{l}158 \\
(49.7 \%)\end{array}$ & & $48(48.0 \%)$ & $53(52.5 \%)$ & $57(48.7 \%)$ & \\
\hline \multicolumn{8}{|c|}{ Serum Sampling Quarter } \\
\hline $\begin{array}{l}1 \text { January - } \\
31 \text { March }\end{array}$ & $\begin{array}{l}126 \\
(29.4 \%)\end{array}$ & $98(30.8 \%)$ & 0.33 & $30(30.0 \%)$ & $35(34.7 \%)$ & $33(28.2 \%)$ & 0.54 \\
\hline $\begin{array}{l}1 \text { April - } 30 \\
\text { June }\end{array}$ & $\begin{array}{l}101 \\
(23.5 \%)\end{array}$ & $90(28.3 \%)$ & & $34(34.0 \%)$ & $24(23.8 \%)$ & $32(27.4 \%)$ & \\
\hline $\begin{array}{l}1 \text { July - } 30 \\
\text { September }\end{array}$ & $96(22.4 \%)$ & $64(20.1 \%)$ & & $17(17.0 \%)$ & $23(22.8 \%)$ & $24(20.5 \%)$ & \\
\hline $\begin{array}{l}1 \text { October - } \\
31 \\
\text { December }\end{array}$ & $\begin{array}{l}106 \\
(24.7 \%)\end{array}$ & $66(20.8 \%)$ & & $19(19.0 \%)$ & $19(18.8 \%)$ & $28(23.9 \%)$ & \\
\hline \multicolumn{8}{|c|}{ Smoking at First Antenatal Visit } \\
\hline No & $\begin{array}{l}297 \\
(69.2 \%)\end{array}$ & $\begin{array}{l}220 \\
(69.2 \%)\end{array}$ & 1.00 & $67(67.0 \%)$ & $74(73.3 \%)$ & $79(67.5 \%)$ & 0.31 \\
\hline Yes & $27(6.3 \%)$ & $20(6.3 \%)$ & & $3(3.0 \%)$ & $5(5.0 \%)$ & $12(10.3 \%)$ & \\
\hline Missing & $\begin{array}{l}105 \\
(24.5 \%)\end{array}$ & $78(24.5 \%)$ & & $30(30.0 \%)$ & $22(21.8 \%)$ & $26(22.2 \%)$ & \\
\hline \multicolumn{8}{|c|}{ Proteins measured in maternal serum samples (median [IQR]) } \\
\hline $\begin{array}{l}\text { A2M } \\
(\mathrm{mg} / \mathrm{ml})\end{array}$ & $\begin{array}{l}2.40(1.60, \\
3.78)\end{array}$ & $\begin{array}{l}2.24(1.55, \\
3.71)\end{array}$ & 0.48 & $\begin{array}{l}2.24(1.58, \\
3.35)\end{array}$ & $\begin{array}{l}2.19(1.66, \\
4.15)\end{array}$ & $\begin{array}{l}2.25(1.45, \\
3.77)\end{array}$ & 0.77 \\
\hline $\operatorname{CRP}(\mu \mathrm{g} / \mathrm{ml})$ & $\begin{array}{l}9.35(3.96, \\
29.97)\end{array}$ & $\begin{array}{l}9.73 \text { (3.31, } \\
3.68)\end{array}$ & 0.80 & $\begin{array}{l}5.81(2.86, \\
2.11)\end{array}$ & $\begin{array}{l}13.04 \\
(5.10 \\
41.30)\end{array}$ & $\begin{array}{l}13.47 \\
(3.85 \\
40.51)\end{array}$ & 0.040 \\
\hline FER (ng/ml) & $\begin{array}{l}85.39 \\
(47.35 \\
148.83)\end{array}$ & $\begin{array}{l}89.23 \\
(44.03 \\
162.51)\end{array}$ & 0.84 & $\begin{array}{l}93.08 \\
(53.00 \\
170.73)\end{array}$ & $\begin{array}{l}90.14 \\
(39.11 \\
159.91)\end{array}$ & $\begin{array}{l}82.74 \\
(43.82 \\
155.07)\end{array}$ & 0.63 \\
\hline FIB (ng/ml) & $\begin{array}{l}3.72(3.18, \\
4.47)\end{array}$ & $\begin{array}{l}3.76(3.16, \\
4.59)\end{array}$ & 0.70 & $\begin{array}{l}3.81(3.15, \\
4.63)\end{array}$ & $\begin{array}{l}3.75(3.28, \\
4.61)\end{array}$ & $\begin{array}{l}3.77(3.14, \\
4.55)\end{array}$ & 0.86 \\
\hline РCT (ng/ml) & $\begin{array}{l}6.56(5.01, \\
8.19)\end{array}$ & $\begin{array}{l}6.63(5.07, \\
8.25)\end{array}$ & 0.66 & $\begin{array}{l}6.81(5.02, \\
8.55)\end{array}$ & $\begin{array}{l}6.36(5.15, \\
7.69)\end{array}$ & $\begin{array}{l}6.77(5.16, \\
8.25)\end{array}$ & 0.80 \\
\hline SAA (ng/ml) & $\begin{array}{l}9.58(5.12, \\
18.35)\end{array}$ & $\begin{array}{l}9.06(4.62, \\
19.60)\end{array}$ & 0.65 & $\begin{array}{l}8.30(4.71, \\
17.53)\end{array}$ & $\begin{array}{l}8.01(4.16, \\
23.04)\end{array}$ & $\begin{array}{l}10.37 \\
(5.27 \\
19.46)\end{array}$ & 0.75 \\
\hline SAP $(\mu \mathrm{g} / \mathrm{ml})$ & $\begin{array}{l}120.50 \\
(64.38 \\
332.40)\end{array}$ & $\begin{array}{l}122.61 \\
(64.66 \\
336.81)\end{array}$ & 0.71 & $\begin{array}{l}99.23 \\
(64.76 \\
232.21)\end{array}$ & $\begin{array}{l}152.39 \\
(73.19 \\
326.99)\end{array}$ & $\begin{array}{l}135.06 \\
(55.28 \\
389.28)\end{array}$ & 0.44 \\
\hline tPA (ng/ml) & $\begin{array}{l}6.52(4.89, \\
8.50)\end{array}$ & $\begin{array}{l}6.54(5.02, \\
9.07)\end{array}$ & 0.46 & $\begin{array}{l}6.24(4.89, \\
8.98)\end{array}$ & $\begin{array}{l}6.89(5.54, \\
9.13)\end{array}$ & $\begin{array}{l}6.46(4.91, \\
8.94)\end{array}$ & 0.75 \\
\hline
\end{tabular}

a. Pearson's chi-squared test was used for categorical variables, comparing the frequency distributions among unaffected individuals to the distributions among all ASD-affected individuals. Kruskal-Wallis tests were used for continuous variables, as the distributions of the APP concentrations were strongly skewed. 
medRxiv preprint doi: https://doi.org/10.1101/2021.03.03.21252813; this version posted March 5, 2021. The copyright holder for this preprint

(which was not certified by peer review) is the author/funder, who has granted medRxiv a license to display the preprint in perpetuity.

It is made available under a CC-BY-NC-ND 4.0 International license.

b. Pearson's chi-squared test was used for categorical variables, comparing the frequency distributions among unaffected individuals to the distribution among the stratified ASD outcome groups. Kruskal-Wallis tests were used for continuous variables, as the distributions of the APP concentrations were strongly skewed.

Abbreviations: ASD: autism spectrum disorders; ADHD: attention-deficit/hyperactivity disorder; ID: intellectual disability; BMI: body mass index; IQR: interquartile range; A2M: $\alpha-2$ macroglobulin;

CRP: C reactive protein; FER: ferritin; FIB: fibrinogen; PCT: procalcitonin; SAA: serum amyloid A; SAP: serum amyloid P; and tPA: tissue plasminogen activator. 
medRxiv preprint doi: https://doi.org/10.1101/2021.03.03.21252813; this version posted March 5, 2021. The copyright holder for this preprint (which was not certified by peer review) is the author/funder, who has granted medRxiv a license to display the preprint in perpetuity.

It is made available under a CC-BY-NC-ND 4.0 International license .

Figure 1. Heat map showing the mean APP z-score by categories of the covariates, among 429 unaffected individuals in the cohort. Solid boxes indicate that the APP is associated with the covariate at $p<0.05$. Dashed boxes indicate that the APP is associated with the covariate at $p<0.20$.

Abbreviations: A2M: $\boldsymbol{\alpha}-2$ macroglobulin; CRP: C-reactive protein; FER: ferritin; FIB: fibrinogen; PCT: procalcitonin; SAA: serum amyloid A; SAP: serum amyloid P; tPA: tissue plasminogen activator;

Psych: Psychiatric; BMI: body mass index; Income Q: income quintile.

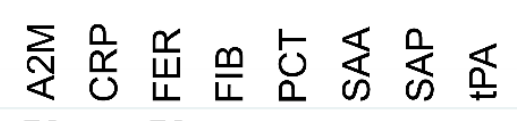

Female fetus $\begin{array}{lllllllll}0.11 & -0.02 & \Gamma_{0}^{0.03} & 0.05 & 0.03 & 0.03 & -0.01 & -0.11\end{array}$

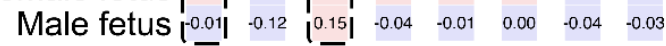

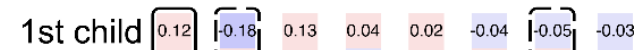

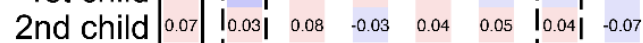

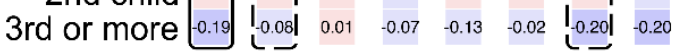

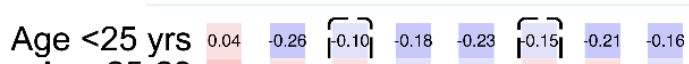
$\begin{array}{lllllllll}\text { Age 25-29 } & 0.17 & 0.04 & |0.02| & -0.03 & -0.02 & |0.11| & 0.02 & -0.09\end{array}$ \begin{tabular}{lll|llllll} 
Age 30-34 & 0.00 & -0.05 & $\left.\right|_{0.18}$ & 0.09 & 0.06 & $\mathbf{I}_{0.06}$ & -0.03 & -0.02
\end{tabular} $\begin{array}{llllllll}\text { Age 35-39 } 0.08 & -0.08 & I_{0.09} & -0.03 & 0.01 & I_{0.04} & 0.07 & -0.16\end{array}$ Age $\geq 40 \quad 0.396 \quad 0.60 \quad\left[\begin{array}{lllllll}0.22 & 0.02 & 0.38 & 0.5 q & 0.40 & 0.48\end{array}\right.$

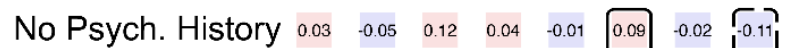
$\begin{array}{lllllllllll}\text { Psych. History } & 0.09 & -0.10 & 0.03 & -0.06 & 0.04 & -0.13 & -0.03 & 0.02 \mid\end{array}$

\begin{tabular}{|c|c|c|c|c|c|c|c|c|}
\hline Underweight & 0.34 & 0.18 & 0.08 & 0.25 & 0.56 & 0.10 & 0.21 & 0.20 \\
\hline Normal weight & 0.04 & -0.24 & 0.05 & 0.01 & 0.02 & -0.04 & -0.13 & -0.08 \\
\hline Overweight & -0.20 & 0.14 & 0.08 & -0.15 & -0.01 & 0.27 & -0.08 & -0.07 \\
\hline Obese & -0.17 & 0.85 & 0.13 & .0 .04 & 0.23 & 0.14 & 0.41 & 0.27 \\
\hline BMI missing & 0.19 & -0.02 & 0.16 & 0.06 & -0.06 & -0.03 & 0.11 & -0.11 \\
\hline Africa & -0.09 & 0.03 & T.39 & 0.44 & 0.79 & 0.05 & -0.13 & -0.01 \\
\hline As & 0.07 & $|0.05|$ & $|-0.10|$ & $0.01 \mid$ & 10.021 & 0.23 & 0.10 & 0.04 \\
\hline Nordic & 0.07 & I.0.09 & $|0.14|$ & lo.ool & $\mathrm{I}_{0.02 \mathrm{I}} \mathrm{i}$ & 0.00 & -0.02 & .0 .11 \\
\hline Other & -0.03 & 0.37 & -0.04 & $I_{0.10}$ & $\mathrm{I}_{0.39}$ & -0.11 & 0.11 & 0.22 \\
\hline Other Eurc & -0.20 & 1.51 & I. & 0.59 & 1 & -0.11 & 0.41 & 0.33 \\
\hline & 0.06 & $\lceil 0.09$ & -0.07 & 0.03 & 0.7 & 0.24 & 0.04 & [0.31 \\
\hline & -0.07 & $1-0.03 \mid$ & -0.05 & -0.14 & 10.201 & 0.04 & -0.16 & $|-0.14|$ \\
\hline Income & 0.06 & $\mathrm{I}_{0.09} \mathrm{I}$ & 0.08 & -0.03 & $L_{0.10}$ & 0.03 & 0.07 & $|-0.11|$ \\
\hline Income & 0.13 & -0.01 & 0.22 & 0.11 & 0.10 & 0.03 & -0.02 & -0.02 \\
\hline Income Q5 & 0.05 & 10.25 & 0.13 & 0.03 & $I_{-10}^{0.10}$ & -0.10 & -0.03 & $\mid$ \\
\hline ducation $<9$ y & -0.08 & F.0.7 & -0.06 & - -0.22 & $\tau_{-0.26}$ & 0.08 & -0.13 & -0.07 \\
\hline Education 9-12 & 0.06 & $\mid 0.03$ & 0.11 & $|0.02|$ & $\mid 0.06$ & 0.03 & 0.01 & -0.07 \\
\hline Education & 0.08 & $-\underbrace{-1}_{-0.18}$ & 0.12 & $\underbrace{}_{0.051}$ & 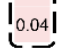 & -0.02 & -0.02 & -0.06 \\
\hline Non-smo & 0.01 & -0.09 & โ0.08 & 0.01 & $\widetilde{0.06}$ & T0.07, & -0.06 & -0.04 \\
\hline Smo & -0.01 & 0.03 & $\mid-0.21$ & -0.28 & -0.15 & $1-0.24$ & -0.05 & -0.05 \\
\hline Missing & 0.18 & .0 .03 & $\underbrace{}_{0.19}$ & 0.06 & -0.101 & -0.081 & 0.07 & -0.15 \\
\hline & 0.00 & -0.23 & 0.10 & 0.04 & 0.00 & 0.04 & $r_{-0.09}$ & -0.07 \\
\hline Sample $\geq 10 \mathrm{wl}$ & 0.10 & 0.08 & 0.08 & -0.02 & 0.01 & 0.00 & 0.031 & -0.07 \\
\hline $1 \mathrm{~J}$ & 0.06 & -0.09 & 0.15 & 0.11 & 0.00 & 0.05 & -0.01 & -0.03 \\
\hline & 0.05 & 0.01 & 0.02 & -0.03 & 0.00 & 0.03 & -0.03 & -0.14 \\
\hline 1 Jul - & 0.11 & -0.13 & 0.16 & -0.04 & 0.04 & -0.04 & -0.04 & 0.07 \\
\hline 1 Oct -31 Dec & -0.01 & -0.06 & 0.02 & -0.04 & 0.00 & 0.02 & -0.02 & -0.17 \\
\hline
\end{tabular}


medRxiv preprint doi: https://doi.org/10.1101/2021.03.03.21252813; this version posted March 5, 2021. The copyright holder for this preprint (which was not certified by peer review) is the author/funder, who has granted medRxiv a license to display the preprint in perpetuity.

It is made available under a CC-BY-NC-ND 4.0 International license.

Figure 2. The relationship between APP and odds of ASD, stratified by co-occurrence of ID and ADHD, when comparing 318 ASD cases to 429 unaffected individuals selected from the cohort.

Tertiles of each APP were created using the distribution of z-scores among unaffected individuals to set the cut-offs and the middle quintile was used as the referent category. Models were adjusted for sex, birth order, maternal BMI, maternal psychiatric history, maternal region of origin, maternal age and family income quintile. P-values are shown for a Wald test with a null hypothesis that all APP categorical terms were jointly equal to zero, as a test of whether each APP was generally associated with the outcome. Abbreviations: A2M: $\alpha-2$ macroglobulin; CRP: C-reactive protein; FER: ferritin; FIB: fibrinogen; PCT: procalcitonin; SAA: serum amyloid A; SAP: serum amyloid P; and tPA: tissue plasminogen activator.
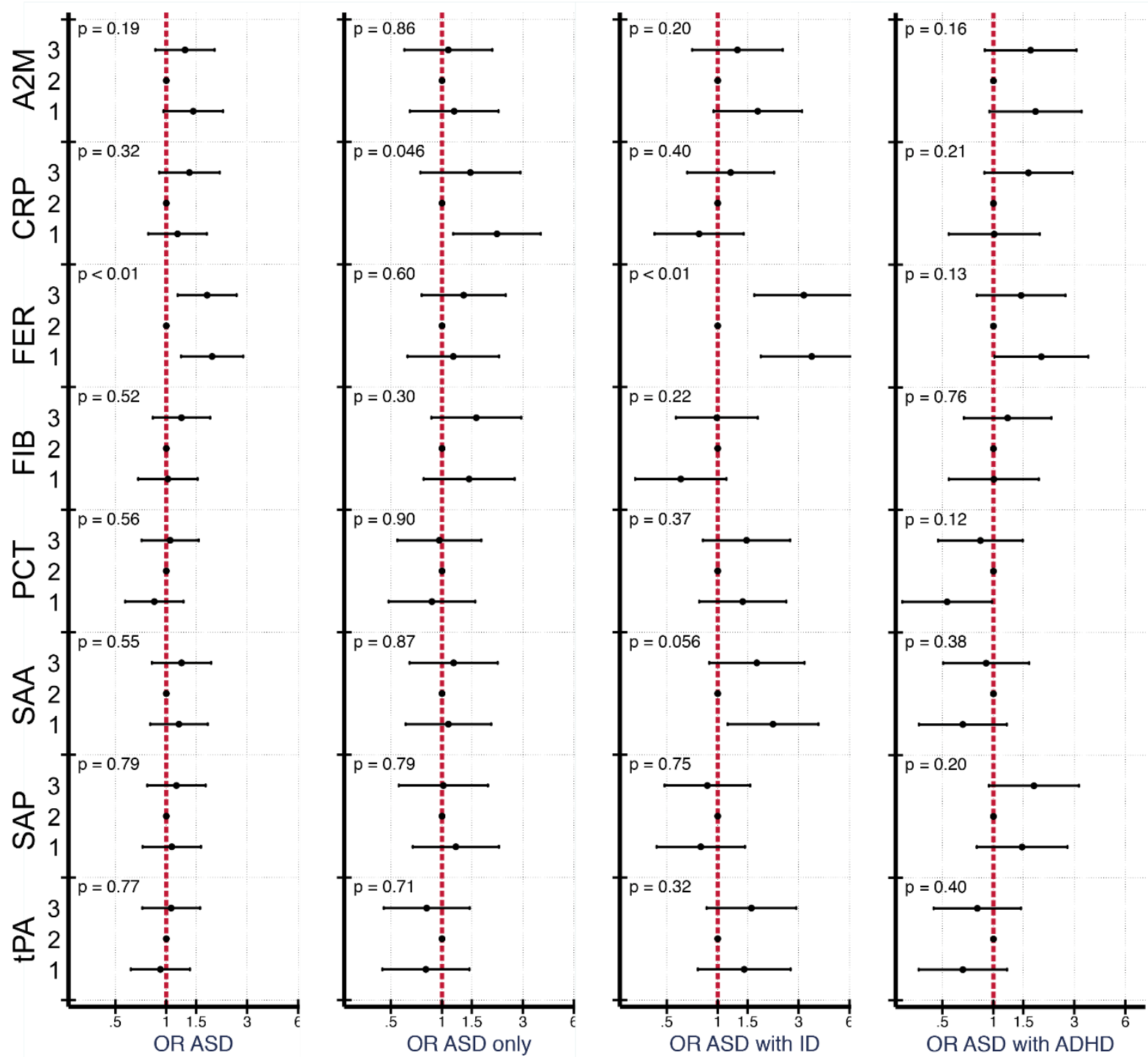
medRxiv preprint doi: https://doi.org/10.1101/2021.03.03.21252813; this version posted March 5, 2021. The copyright holder for this preprint (which was not certified by peer review) is the author/funder, who has granted medRxiv a license to display the preprint in perpetuity.

It is made available under a CC-BY-NC-ND 4.0 International license .

Figure 3. The relationship between APP and odds of ASD when comparing 318 individuals affected by ASD to 429 unaffected individuals selected from the cohort. Each panel displays the odds of ASD according to APP z-score, flexibly fit using restricted cubic spline models with three knots and a zscore $=0$ as the referent. The dashed line represents the unadjusted estimate of the relationship between each APP and odds of ASD. The solid line represents the fully adjusted model, adjusted for sex, birth order, maternal BMI, maternal psychiatric history, maternal region of origin, maternal age and family income quintile. The gray bands represent the $95 \%$ confidence interval for the fully adjusted model. P-values are shown for a Wald test with a null hypothesis that all APP spline terms were jointly equal to zero, as a test of whether each APP was generally associated with the outcome.

Abbreviations: A2M: $\alpha-2$ macroglobulin; CRP: C-reactive protein; FER: ferritin; FIB: fibrinogen; PCT: procalcitonin; SAA: serum amyloid A; SAP: serum amyloid P; and tPA: tissue plasminogen activator.
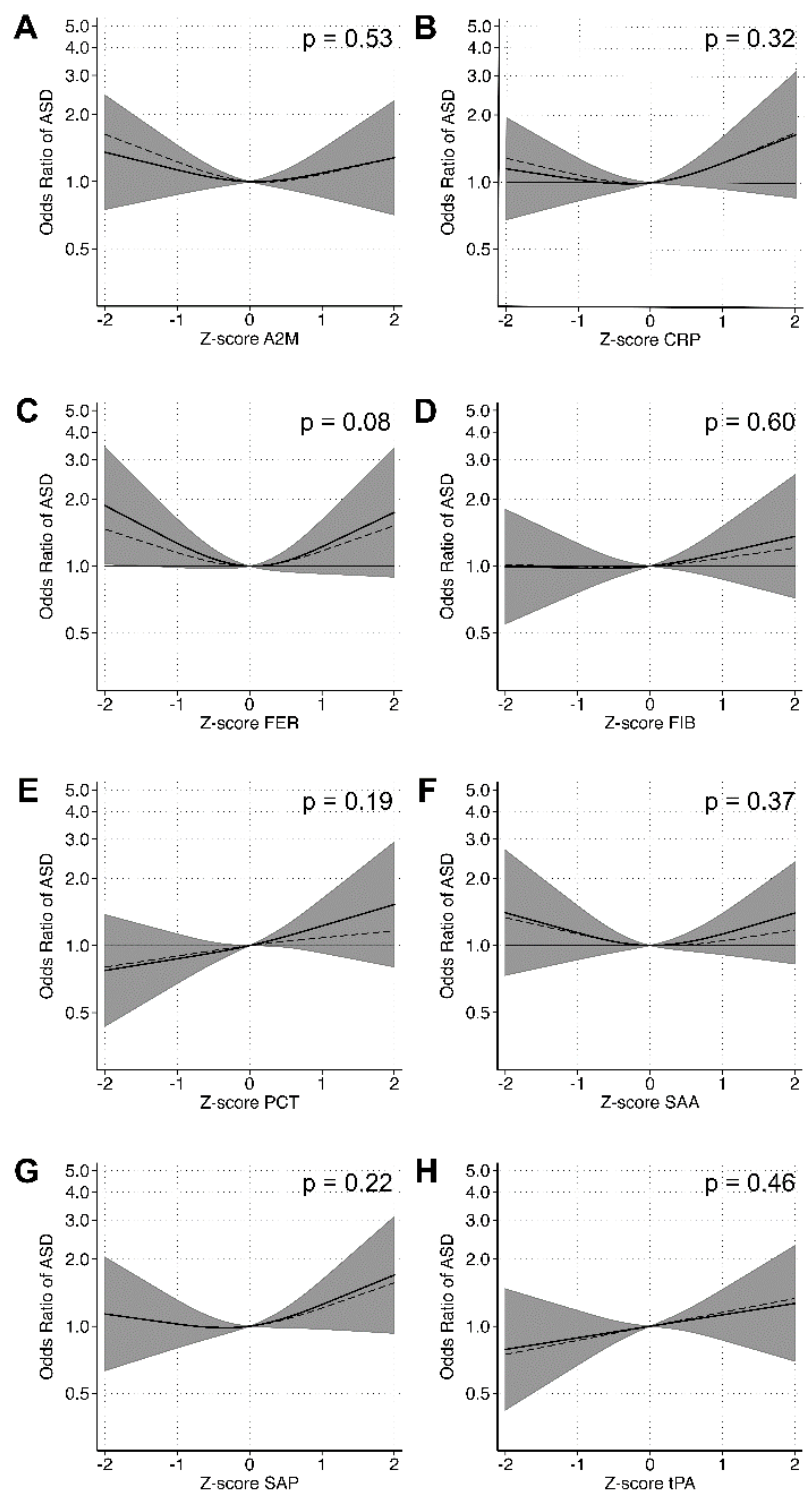